\title{
Relationship Between Muscle Mass and Insulin Resistance in Cirrhotic Patients with Hepatitis B
}

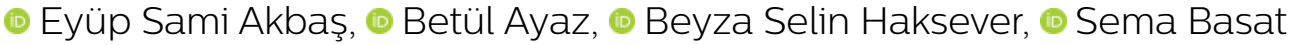

Department of Internal Diseases,
Istanbul Ümraniye Training and
Research Hospital, Istanbul, Turkey

\begin{abstract}
Objective: Hepatitis B virus (HBV) affects over 400 million people in the world and is a major threat despite all measures taken for its prevention. It is one of the most important causes of liver cirrhosis. Liver cirrhosis causes malnutrition as a result of decreased oral intake, both because of the disease itself and multiple other reasons. Studies showed an inverse correlation between muscle mass and insulin resistance. We aimed to evaluate the relationship between insulin resistance, muscle mass, and muscle strength in patients with HBV-related cirrhosis.
\end{abstract}

Methods: We included 65 patients with HBV-related cirrhosis in Child-Pugh class A and B groups and 65 healthy control individuals in this monocentric study. Muscle mass indices were calculated with bioimpedance analysis for both groups to determine muscle strength and muscle mass. Handgrip strength, arm, and calf circumferences were measured. In both groups, HOMA-IR values were calculated to determine insulin resistance. Correlations of fasting glucose, fasting insulin, HbAIC, LDL, HDL, triglyceride, and cholesterol levels with calf and waist circumference measurements were detected. The relationship between muscle mass and insulin resistance, laboratory results, and waist and calf circumference was evaluated.

Results: The mean value of muscle mass index was $10.98 \pm 11.40 \mathrm{~kg} / \mathrm{m}^{2}$ in cirrhotic patients and $9.88 \pm \mathrm{I} .12 \mathrm{~kg} / \mathrm{m}^{2}$ in healthy control individuals. HOMA-IR values were detected as $3.47 \pm 3.80$ in the study group and $1.83 \pm 1.20$ in the control group. The correlation coefficient between muscle mass and insulin resistance was statistically insignificant, especially in the study group.

Conclusion: In our study, there was no relationship between muscle mass and insulin resistance in cirrhotic patients with hepatitis B.

\section{INTRODUCTION}

The liver has more than one metabolic function and uses $20 \%$ of the total energy of an individual. In the later stages of liver cirrhosis, protein-energy malnutrition is a frequently seen clinical picture. Malnutrition is present in $20 \%$ of compensated and $60 \%$ of decompensated patients with liver cirrhosis. ${ }^{[1]}$ These patients are said to have malnutrition as compared to the normal population and lower than normal muscle mass.

Increased lipid oxidation and decreased glucose oxidation have been observed in patients with cirrhosis. Majority of cirrhotic patients have impaired glucose tolerance along with insulin resistance and hyperinsulinemia. ${ }^{[2]}$

Skeletal muscle plays an important role in glucose metabolism and removes $80 \%-90 \%$ of postprandial insulinstimulated glucose. Therefore, many studies have been carried out on skeletal muscles, which are insulin-resistant regions. As a result of the studies performed, it has been suggested that skeletal muscle is primarily responsible for the impaired insulin effect which involves the glycogen synthesis pathway. ${ }^{[3]}$

Studies have shown that there is an inverse relationship between increased muscle mass and insulin resistance, and it has been determined that patients with low muscle mass are more predisposed to diabetes mellitus. ${ }^{[4]}$

In our study, we aimed to determine sarcopenia in cirrhotic patients and assess the relationship between components of sarcopenia and insulin resistance.

\section{MATERIALS AND METHODS}

Prior to the study, Ethics Committee approval was obtained on 17 April 2017 (no. 8727) from the Department 
of Clinical Research Ethics Committee of Umraniye Education and Research Hospital. Informed consent was obtained from all patients and the control group before they were being enrolled in the study.

Sixty-five Child-Pugh class A and B HBV-related cirrhotic patients and 65 control patients without any chronic disease were included in our study. Patients in the control group were selected from those who had applied to internal medicine outpatient clinics with no abnormality in their routine examinations. In order to determine the muscle mass in both groups, the muscle mass index was determined using bioimpedance analysis based on the following formula: [length $\left.{ }^{2} / \mathrm{R} \times 0.40 \mathrm{I}\right]+(\operatorname{sex} \times 3.825)+($ age $x-0.07 I)]+5.102$.

The values found were divided by the square of the height in meters $\left(\mathrm{kg} / \mathrm{m}^{2}\right)$. Handgrip strength, arm, and calf circumference were measured.

The arm circumference was measured with a measuring tape wrapped to fit around the highest point of the biceps and the lowest point of the triceps muscles. The calf circumference was measured from the most bulging part of the leg by wrapping the tape around the leg. Glucose, total cholesterol, HDL, triglyceride levels were measured in whole blood by enzymatic calorimetric method (Hitachi 747 autoanalyzer, Mito, Ibaragi, Japan). LDL levels were calculated with the Friedewald formula. HbAlc levels were measured using the HPLC method. Normal handgrip strength was accepted as $30 \mathrm{mmHg}$ in men and 20 $\mathrm{mmHg}$ in women. HOMA-IR [(fasting insulin IU / $\mathrm{mL}) X$ (FBG mmol / L) / 22.5] was evaluated in order to determine insulin resistance in both groups. The upper limit of HOMA-IR was accepted as 3.2.

\section{Statistical analysis}

In the evaluation of the findings obtained in the study, SPSS for Windows 22.0 program was used for statistical analysis. In the evaluation of the study data, descriptive statistical methods (mean, standard deviation, \% frequency) for the comparison of qualitative data such as the chi-square test and Fisher exact test were used. The relationship between handgrip strength and muscle mass index measurements with other parameters was examined by correlation and regression analysis. The comparison of all research parameters between the patient and healthy group was performed using an independent t-test. Significance was evaluated at $p<0.05$ and $p<0.01$.

\section{RESULTS}

The study group (78 men: 60\%, and 52 women: $40 \%$ ) consisted of $65(50 \%)$ patients and $65(50 \%)$ control subjects. The mean ages of the patient and the healthy groups were significantly different from each other $(p<0.05)$. The mean age of the patient group (55.4I54 10.84967 years) was found to be higher than the mean age $(36.8154 \pm 11.18159$ years) of the healthy group.

\section{Comparison of all parameters in patient and healthy groups}

Comparison of the patient and healthy groups in terms of all parameters was achieved (Table I).

There was a significant difference between the patients and the healthy subjects because of the existence of probability levels $(p<0.05)$ in the arm circumference, fasting insulin, fasting glucose, HOMA-IR, HDL, and total cholesterol.

\section{Investigation of The Relationship between all Parameters and Muscle Mass Index and Handgrip Strength in the Patient Group using Correlation Analysis}

In the patient group, muscle mass index correlated positively with handgrip strength $(.592 * *)$, and calf circumference $\left(.416^{* *}\right)$.

Handgrip strength correlated positively, and significantly with muscle mass index $\left(672^{* *}\right)$, calf $\left(335^{* *}\right)$, and waist circumferences $\left(303^{*}\right)$ (Table 2 ).

Table I. Comparison of all parameters in the patient, and the healthy groups

\begin{tabular}{|c|c|c|c|}
\hline Variable & Group & Mean $\pm S D$ & $\mathbf{P}^{\prime}$ \\
\hline Muscle mass index & Patient & $10.985 \pm 11.40$ & 0.438 \\
\hline$\left(\mathrm{kg} / \mathrm{m}^{2}\right)$ & Healthy & $9.88 \pm 1.12$ & \\
\hline Handgrip strength & Patient & $29.48 \pm 8.42$ & 0.263 \\
\hline$(\mathrm{mmHg})$ & Healthy & $31.28 \pm 9.80$ & \\
\hline Arm circumference & Patient & $29.43 \pm 3.55$ & $0.001^{* *}$ \\
\hline$(\mathrm{cm})$ & Healthy & $32.28 \pm 5.86$ & \\
\hline Calf circumference & Patient & $46.80 \pm 5.57$ & 0.616 \\
\hline$(\mathrm{cm})$ & Healthy & $47.29 \pm 5.59$ & \\
\hline Waist circumference & Patient & $98.98 \pm 11.05$ & 0.096 \\
\hline$(\mathrm{cm})$ & Healthy & $95.38 \pm 13.35$ & \\
\hline Fasting blood & Patient & $13.63 \pm 13.72$ & $0.002^{* *}$ \\
\hline insulin (ulU/mL) & Healthy & $7.85 \pm 4.24$ & \\
\hline Fasting blood & Patient & $98.63 \pm 14.70$ & $0.009^{* *}$ \\
\hline glucose (mg/dL) & Healthy & $92.58 \pm 10.94$ & \\
\hline \multirow[t]{2}{*}{ HBAIC } & Patient & $5.51 \pm .47$ & 0.705 \\
\hline & Healthy & $5.48 \pm .36$ & \\
\hline \multirow[t]{2}{*}{ HOMA-IR } & Patient & $3.47 \pm 3.80$ & $0.00 I^{* *}$ \\
\hline & Healthy & $1.83 \pm 1.20$ & \\
\hline \multirow[t]{2}{*}{ LDL (mg/dL) } & Patient & $109.05 \pm 37.69$ & 0.316 \\
\hline & Healthy & II $5.88 \pm 39.72$ & \\
\hline \multirow[t]{2}{*}{$\mathrm{HDL}(\mathrm{mg} / \mathrm{dL})$} & Patient & $40.20 \pm 12.65$ & $0.001^{* *}$ \\
\hline & Healthy & $46.91 \pm 10.67$ & \\
\hline Total cholesterol & Patient & $170.48 \pm 43.90$ & $0.034^{*}$ \\
\hline$(\mathrm{mg} / \mathrm{dL})$ & Healthy & $186.66 \pm 42.26$ & \\
\hline \multirow[t]{2}{*}{ Triglyceride (mg/dL) } & Patient & $106.98 \pm 54.25$ & 0.373 \\
\hline & Healthy & $116.09 \pm 61.70$ & \\
\hline
\end{tabular}

" $\mathrm{P}<0.05 ;{ }^{* *} \mathrm{p}<0.01$; 'Independent sample t-test $\mathrm{p}$ value.

HOMA-IR: Homeostatic Model of Assessment-Insulin Resistance; LDL: Low density lipoprotein; HLD: High density lipoprotein; SD: Standard deviation. 
Table 2. Correlation analysis of all parameters in the patient group

\begin{tabular}{|c|c|c|c|c|c|c|c|c|c|c|c|c|c|c|}
\hline No & Variable & I & 2 & 3 & 4 & 5 & 6 & 7 & 8 & 9 & 10 & II & 12 & 13 \\
\hline I & MMI & I & & & & & & & & & & & & \\
\hline 2 & HGS & $0.592^{* *}$ & 1.000 & & & & & & & & & & & \\
\hline 3 & $A C$ & 0.143 & 0.155 & 1.000 & & & & & & & & & & \\
\hline 4 & $\mathrm{CC}$ & $0.416^{* *}$ & $0.335^{* *}$ & $0.495^{* *}$ & 1.000 & & & & & & & & & \\
\hline 5 & WC & $0.310^{*}$ & $0.303^{*}$ & $0.548^{* *}$ & $0.536^{* *}$ & 1.000 & & & & & & & & \\
\hline 6 & $\mathrm{FBI}$ & 0.205 & 0.192 & $0.338^{* *}$ & $0.290^{*}$ & $0.455^{* *}$ & 1.000 & & & & & & & \\
\hline 7 & FBG & 0.053 & -0.031 & -0.046 & 0.149 & $0.297^{*}$ & $0.447^{* *}$ & 1.000 & & & & & & \\
\hline 8 & Hbalc & -0.062 & -0.020 & 0.020 & -0.039 & $0.254^{*}$ & 0.032 & $0.467^{* *}$ & 1.000 & & & & & \\
\hline 9 & Homa-IR & 0.197 & $0.17 \mid$ & $0.308^{*}$ & $0.289^{*}$ & $0.474^{* *}$ & $0.986^{* *}$ & $0.558^{* *}$ & 0.083 & 1.000 & & & & \\
\hline 10 & LDL & -0.129 & -0.013 & 0.092 & 0.215 & 0.136 & 0.014 & 0.052 & $0.422^{* *}$ & -0.012 & 1.000 & & & \\
\hline II & HDL & -0.116 & -0.073 & -0.116 & 0.028 & $0-.228$ & -0.082 & 0.105 & -0.097 & -0.073 & 0.138 & 1.000 & & \\
\hline 12 & TC & -0.167 & 0.004 & 0.114 & 0.238 & 0.096 & 0.041 & 0.029 & $0.353^{* *}$ & 0.008 & $0.950^{* *}$ & $0.300^{*}$ & 1.000 & \\
\hline 13 & TG & -0.117 & 0.095 & $0.250^{*}$ & 0.213 & $0.260^{*}$ & 0.231 & -0.073 & 0.175 & 0.196 & $0.305^{*}$ & $-0.396^{* *}$ & $0.373^{* *}$ & 1 \\
\hline
\end{tabular}

${ }^{*}<<0.05$; ${ }^{* *} \mathrm{P}<0.01$; 'Spearman correlation. FBI: Fasting blood insulin; TG: Triglyceride; TC: Total cholesterol; FBG: Fasting blood glucose; WC: Waist circumference; AC: Arm circumference; CC: Calf: Circumference; HGS: Handgrip Strength; MMI: Muscle mass index.

Table 3. Regression analysis of variables effective on muscle mass index in the patient group

\begin{tabular}{|c|c|c|c|c|c|c|c|}
\hline \multirow[t]{2}{*}{ Group } & \multirow[t]{2}{*}{ Model } & \multicolumn{2}{|c|}{ Unstd. Coefficients } & \multirow{2}{*}{$\frac{\text { Std Coefficients }}{\text { Beta }}$} & \multirow[t]{2}{*}{$\mathbf{t}$} & \multirow[t]{2}{*}{$\mathbf{p}$} & \multirow[t]{2}{*}{$\mathbf{R}^{2}$} \\
\hline & & B & Std. Error & & & & \\
\hline \multirow[t]{2}{*}{ Handgrip } & Patient & & & & & & \\
\hline & Healthy & 0.097 & 0.170 & 0.072 & 0.572 & 0.570 & $0 \%$ \\
\hline \multirow[t]{2}{*}{ Strength $(\mathrm{mmHg})$} & Patient & & & & & & \\
\hline & Healthy & 0.074 & 0.011 & 0.645 & 6.699 & $0.000^{* *}$ & $41.6 \%$ \\
\hline \multirow[t]{3}{*}{ Waist circumference $(\mathrm{cm})$} & Patient & & & & & & \\
\hline & Healthy & 0.286007 & 0.125 & 0.277 & 2.290 & $0.025^{*}$ & $8.3 \%$ \\
\hline & & & 0.011 & 0.085 & 0.675 & 0.502 & $0 \%$ \\
\hline \multirow[t]{3}{*}{$\mathrm{HDL}(\mathrm{mg} / \mathrm{dL})$} & Patient & & & & & & \\
\hline & Healthy & -0.116 & 0.113 & -0.188 & -1.116 & 309 & $0 \%$ \\
\hline & & -0.042 & 0.012 & -0.474 & -4.267 & 0.000 & $22.4 \%$ \\
\hline
\end{tabular}

${ }^{*} \mathrm{p}<0.05 ;{ }^{* *} \mathrm{p}<0.0$ I; 'Linear regression coefficients t test $\mathrm{p}$ value. HLD: High density lipoprotein.

\section{Regression analysis of the explanatory status of the relevant parameters for the variables of mus- cle mass index and handgrip in the patient group}

The regression analysis revealed the impact of relationships found in the correlation analysis in detail. In regression analysis, only statistically significant variables of correlation analysis were used as independent variables.

In the patient group, muscle mass index affected the waist circumference positively $(.915 *)$. Increased waist circumference could be interpreted as an increase in muscle mass (Table 3).

In the patient group, the calf $\left(.558^{* *}\right)$ and waist circumference $\left(.22 I^{*}\right)$ affected the handgrip strength positively (Table 4).

4. Comparison of handgrip strength groups of female and male participants in the patient and healthy groups
The parameter of handgrip strength is evaluated differently in men and women. For this purpose, handgrip strength was grouped as HGS $<30 \mathrm{mmHg}$ and $\mathrm{HGS} \geq 30 \mathrm{mmHg}$ in males, and as HGS $<20 \mathrm{mmHg}$ and HGS $\geq 20 \mathrm{mmHg}$ in females. Patients and healthy individuals in each gender group were compared in consideration with this grouping. In male participants, because of the detection of a test probability level of $p<0.05$ between HGS groups and health status of the study participants, a correlation is found between these parameters. Indeed, all participants in the HGS $<30 \mathrm{mmHg}$ group consisted of patients, while $64.3 \%$, and $35.7 \%$ of $\mathrm{HGS} \geq 30 \mathrm{mmHg}$ group comprised of patients and healthy individuals, respectively.

In female participants; because of the detection of a test probability level of $p<0.05$ ), a significant relationship between the HGS groups and health status of the participants existed. While $43.8 \%$ of the patients in the HGS $<20$ $\mathrm{mmHg}$ group consisted of sick individuals, only $13.9 \%$ of 
Table 4. Regression analysis of variables affecting handgrip strength in the patient group

\begin{tabular}{|c|c|c|c|c|c|c|c|}
\hline \multirow[t]{2}{*}{ Variable } & \multirow[t]{2}{*}{ Group } & \multicolumn{2}{|c|}{ Unstd. Coefficients } & \multirow{2}{*}{$\frac{\text { Std Coefficients }}{\text { Beta }}$} & \multirow[t]{2}{*}{$\mathbf{t}$} & \multirow[t]{2}{*}{$\mathbf{p}$} & \multirow[t]{2}{*}{$\mathbf{R}^{2}$} \\
\hline & & B & Std. Error & & & & \\
\hline \multirow[t]{3}{*}{ Muscle mass index $\left(\mathrm{kg} / \mathrm{m}^{2}\right)$} & Patient & & & & & & \\
\hline & Healthy & 0.053 & 0.093 & 0.072 & 0.572 & 0.570 & $0 \%$ \\
\hline & & 5.620 & 0.839 & 0.645 & 6.699 & $0.000^{* *}$ & $64.5 \%$ \\
\hline \multirow[t]{2}{*}{ Calf circumference $(\mathrm{cm})$} & Patient & 0.558 & 0.177 & 0.369 & 3.155 & $0.002^{* *}$ & $13.6 \%$ \\
\hline & Healthy & 0.262 & 0.218 & 0.150 & 1.202 & 0.234 & $0 \%$ \\
\hline \multirow[t]{2}{*}{ Waist circumference $(\mathrm{cm})$} & Patient & 0.221 & 0.092 & 0.290 & 2.403 & 0.019 & $8.4 \%$ \\
\hline & Healthy & 0.104 & 0.092 & 0.141 & 1.132 & 0.262 & $\% 0$ \\
\hline \multirow[t]{2}{*}{$\mathrm{HDL}(\mathrm{mg} / \mathrm{dL})$} & Patient & 0.028 & 0.084 & 0.042 & 0.334 & 0.739 & $0 \%$ \\
\hline & Healthy & -0.410 & 0.104 & -0.447 & -3.963 & 0.000 & $18.7 \%$ \\
\hline
\end{tabular}

${ }^{*} \mathrm{p}<0.05$; ${ }^{* *}<<0.01$; 'Linear regression coefficients $t$ test $\mathrm{p}$ value. HLD: High density lipoprotein.

Table 5. Comparison of the patient, and healthy groups in terms of handgrip strength

\begin{tabular}{|c|c|c|c|c|c|c|}
\hline \multirow[t]{2}{*}{ Gender } & & & \multicolumn{2}{|c|}{ Handgrip strength $(\mathrm{mmHg})$} & \multirow[t]{2}{*}{ Total } & \multirow[t]{2}{*}{$\mathbf{p}^{\prime}$} \\
\hline & & & Handgrip strength $<30$ & Handgrip strength $\geq 30$ & & \\
\hline \multirow[t]{4}{*}{ Men } & Group, n (\%) & Patient & $8(100)$ & $45(64.3)$ & $53(67.9)$ & $0.049^{*}$ \\
\hline & & Healthy & $0(0.0)$ & $25(35.7)$ & $25(32.1)$ & \\
\hline & & Total & $8(100.0)$ & $70(100.0)$ & $78(100.0)$ & \\
\hline & & & Handgrip strength $<20$ & Handgrip strength $\geq 20$ & & \\
\hline \multirow[t]{3}{*}{ Women } & Group, n (\%) & Patient & $7(43.8)$ & $5(13.9)$ & $12(23.1)$ & $0.031^{*}$ \\
\hline & & Healthy & $9(56.2)$ & $31(86.1)$ & 40 (76.9) & \\
\hline & & Total & $16(100.0)$ & $36(100.0)$ & $52(100.0)$ & \\
\hline
\end{tabular}

" $p<0.05 ;{ }^{* *} p<0.01 ;$ I: (Chi-square) Fisher exact test $p$ value.

Table 6. Comparison of HOMA-IR values in the patient, and healthy groups

\begin{tabular}{ccccc}
\hline & \multicolumn{2}{c}{ Group } & Total & $\mathbf{p}^{\prime}$ \\
\cline { 2 - 4 } & Patient & Healthy & & \\
\hline Homa-IR groups & & & & \\
$<3.2$ & $43(68.3)$ & $58(89.2)$ & $101(78.9)$ & $0.005^{* *}$ \\
$\geq 3.2$ & $20(31.7)$ & $7(10.8)$ & $27(21.1)$ & \\
Total & $63(100.0)$ & $65(100.0)$ & $128(100.0)$ & \\
& & &
\end{tabular}

" $p<0.05$; " $p<0.0$ I; 'Chi-square $p$ value. HOMA-IR: Homeostatic Model of Assessment-Insulin Resistance.

the patients in the ESG $\geq 20 \mathrm{mmHg}$ group were included in the study (Table 5).

\section{Comparison of HOMA-IR groups in patient and healthy groups}

The study participants were divided into two groups as those having HOMA-IR values of $<3.2$ or $\geq 3.2$, and it was investigated whether this distinction led to a significant proportional collection among patients and healthy individuals.

Because the test probability level was $p<0.05$, the proportional relationship between HOMA-IR parameter groups and health status of the participants was found to be significant

In the healthy group, $82.9 \%$ of the individuals were in the HOMA-IR (<3.2) group and $10.8 \%$ in the HOMA-IR ( $\geq 3.2$ ), group while $68.3 \%$ of the patients in the patient group were in HOMA-IR $(<3.2)$ group and $31.7 \%$ of them in HOMA-IR ( $\geq 3.2)$ group. When compared with healthy individuals, a greater number of patients were in the HOMA-IR ( $\geq 3.2$ ) group (Table 6).

\section{DISCUSSION}

There is no relationship between muscle mass and insulin resistance in Child-Pugh A and B class cirrhotic patients with hepatitis. In the advanced stages of liver cirrhosis, protein-energy malnutrition is a frequently seen clinical picture. Malnutrition is present in $20 \%$ of compensated and $60 \%$ of decompensated liver cirrhosis patients. ${ }^{[1]}$ These patients may have malnutrition and lower muscle mass as compared to the normal population.

End-stage liver disease can be defined as cachexia accompanied by sarcopenia. Sarcopenia refers to the progressive generalized loss of muscle mass and muscle strength. ${ }^{[5]}$ Increased insulin resistance in these patients means hyper- 
insulinemia and hyperglycemia. Hyperglycemia and hyperinsulinemia have a negative effect on prognosis in patients with any critical disease.

Regardless of the etiology, most of the cirrhotic patients are malnourished and sarcopenic. There is a relationship between the density of muscle mass and insulin resistance and some metabolic values. ${ }^{[4]}$

In our study, presence of severe sarcopenia was considered in patients with muscle mass indices (MMls) of $\leq 8.5$ $\mathrm{kg} / \mathrm{m}^{2}$ in men and $5.75 \mathrm{~kg} / \mathrm{m}^{2}$ in women, while MMls of $10.76 \mathrm{~kg} / \mathrm{m}^{2}$ in men and $\geq 6.76 \mathrm{~kg} / \mathrm{m}^{2}$ in women were regarded as normal MMls. ${ }^{[6]}$

Accordingly, 6 male patients in the patient group were severely sarcopenic. Of the 65 patients, II female and II male patients had normal muscle mass indices. We could classify 37 patients as being moderately sarcopenic.

The original version of Child-Turcotte classification, which determines the prognosis of patients with liver cirrhosis, was used until the year 1973 and had taken the nutritional status of the patients in consideration. In the more recent modified Child-Pugh classification, this has been replaced by prothrombin time. Malnutrition rate in cirrhosis was earlier observed at $80 \%$ and an increase in the malnutrition rate by up to $25 \%$ has been reported even in Child-Pugh class $A$ patients. ${ }^{[7]}$ In the 2006 guidelines of European Society for Clinical Nutrition and Metabolism (ESPEN), malnutrition is defined as a condition that causes measurable negative effects and clinical results in a tissue/body form (shape, size and composition) and functions as an outcome of a deficiency or excess (i.e. imbalance) of energy, proteins, and other nutrients. ${ }^{[8]}$ Cirrhotic patients are malnourished in terms of protein intake due to both reduced intake and hypermetabolic conditions. In our study, no significant difference was found between the patient and the healthy group in terms of muscle mass and its functions.

It is thought that the introduction of muscle mass measurement into clinical practice in the diagnosis of sarcopenia may be possible with bioimpedance analysis (BIA). Indeed, according to other muscle measurement methods, muscle mass measurement with BIA is a more practical application. ${ }^{[9,10]}$ Studies on bioimpedance analysis have mostly been conducted in human populations under the age of 65 years. Impedance measurements in elderly individuals can overestimate lean muscle mass, so body fat can be underestimated. ${ }^{[10]}$

Insulin resistance is a pathological condition that is usually associated with chronic and usually low-grade inflammation, such as metabolic syndrome, type- 2 diabetes, atherosclerosis, cancer, rheumatoid arthritis, and polycystic ovary syndrome. ${ }^{\left[{ }^{I I]}\right.}$ It is not known exactly how chronic low-grade inflammation occurs in these diseases, but it is thought to play an important role in the formation of insulin resistance. ${ }^{[12]}$ If we consider that there is a low degree of inflammation in patients with cirrhosis, the possibility of insulin resistance in these patients should not be overlooked.
In our study, we aimed to determine the relationship between muscle mass and insulin resistance in patients with hepatitis B-induced liver cirrhosis. Despite the presence of advanced diagnostic and therapeutic methods used today, HBV continues to be an important issue as it infects approximately 400 million people worldwide. ${ }^{[3]}$

Many studies have been conducted concerning chronic liver diseases and impaired glucose tolerance. ${ }^{[14-16]}$ However, a very small number of studies have examined the relationship between diabetes mellitus (DM) and hepatitis B. Obesity, advanced age, and family history are risk factors for DM, while cirrhosis, liver fatigue, and hepatitis C have been implicated as a risk factor for DM. ${ }^{[17-19]}$ In clinical studies based on experimental studies indicating the relationship between DM and IR and chronic HBV, it has been reported that the incidence of type 2 diabetes is higher in patients with chronic HBV and HCV and that gestational diabetes can be seen more frequently in relation to $\mathrm{Hb}$ sAg- positivity. ${ }^{[20,21]}$

A negative correlation was determined between skeletal muscle index and insulin resistance, $\mathrm{HbAlc}$ and prevalence of diabetes, and prediabetes in The Third National Health and Nutrition Examination Survey. Consistent with these studies, an increase in mRNA expression of a peptide called myostatin that negatively affects the skeletal muscle mass was also determined in the muscles of patients with type 2 diabetes. ${ }^{[4,22]}$ In our study, no correlation was found between skeletal muscle mass and Homa-IR evaluated for the presence of insulin resistance. We can associate this finding with a small number of study participants.

Loss of skeletal muscle mass and presence of insulin resistance in skeletal muscle are associated with the aging process and obesity which can form the basis of metabolic dysregulation and contribute to the development of MS. ${ }^{[23]}$ In our study, no significant difference between the healthy and the patient groups in terms of muscle mass was detected.

A significant difference was found between HOMA-IR, fasting insulin, and fasting glucose levels in the comparison of all parameters in the patient and healthy groups. In these three different parameters, the mean values in the healthy group were found to be comparatively lower. This may indicate that cirrhotic patients are more likely to experience impaired fasting glucose, prediabetes, and insulin resistance when compared with a healthy population.

The term sarcopenia is of Greek origin and consists of a combination of the words sarx (muscle) and penia (loss). It expresses the progressive generalized loss of muscle mass and muscle strength. ${ }^{[5]}$ Sarcopenia is generally associated with reduced mobility, physical inactivity, slow walking, and poor physical endurance, and is also a common feature of frailty syndrome. ${ }^{[24]}$

The diagnostic criteria of sarcopenia are low muscle mass, low muscle strength, and low physical performance. There are not many methods for assessing muscle strength in these patients. Handgrip strength is used to measure mus- 
cle strength. In our study, significant positive relationships were detected between handgrip strength and muscle mass index, calf circumference, and waist circumference in the patient group which means that the muscle mass increases in parallel with the handgrip strength in the patient group.

In the study of by Laurentani et al., it was determined that in clinical practice, the handgrip strength of $30 \mathrm{mmHg}$ for men and $20 \mathrm{mmHg}$ for women would be a good approach. The use of handgrip is a convenient screening method because its application is easy, fast, and relatively inexpensive. However, exercise can lead to different effects on different muscle groups and should be monitored by appropriate regional methods. Furthermore, handgrip strength may not be strongly correlated with muscle strength in patients affected by rheumatoid arthritis, osteoarthritis, and carpal tunnel syndrome. ${ }^{[25]}$

In our study, handgrip strength was used to evaluate muscle strength. Here, the test limit was considered as $30 \mathrm{mmHg}$ for men and $20 \mathrm{mmHg}$ for women. Among male participants; a correlation between the HGS groups and the patient and the health status was detected at a test probability value of $<0.05$. All patients in the HGS $<30 \mathrm{mmHg}$ group consisted of sick individuals, while the HGS $\geq 30 \mathrm{mmHg}$ group consisted of patients $(64.3 \%)$ and healthy individuals (35.7\%). In other words, when we consider the upper limit of normal value of muscle strength in the male patient group, we can say that most $(45 / 53)$ of the patients were within the normal range. Among the female participants included in the study, the test probability level $(p<0.05)$ indicated the presence of a significant correlation between the HGS groups and the health status of the study participants. Sick individuals consisted of $43.8 \%$ and $13.9 \%$ of the study participants in the HGS $<20 \mathrm{mmHg}$ and HGS $\geq 20 \mathrm{mmHg}$ groups, respectively. We can say that handgrip strength in the female patient group is lower than the upper limit of normal.

In our study, HOMA-IR levels were estimated in the patient and control groups in order to determine insulin resistance. The participants were divided into two groups in consideration of 3.2 as the upper limit of normal and the presence of a significant proportional accumulation was investigated in patient and healthy individuals if any. Since the test probability level $(p)$ was $<0.05$, a significant proportional relationship was determined between HOMA-IR parameter groups and health status of the study participants. In other words, the number of sick individuals was higher than the patients in the HOMA-IR $\geq 3.2$ group. In our study, the incidence of insulin resistance in cirrhotic patients was higher than the healthy population. This result demonstrates similarities with the outcomes of previous studies.

The main aim of this study was to determine the relationship between muscle mass and insulin resistance in a special group, namely in hepatitis B-induced cirrhotic patients. The correlation between muscle mass and HOMA-IR levels was not statistically significant.

\section{CONCLUSION}

In our study, no significant relationship was found between muscle mass index and handgrip strength and HOMA-IR values in both patients and healthy participants. This can be attributed to the small number of our patients, limited survey time, and perhaps the fact that the muscle mass in the cirrhotic patients is difficult to estimate objectively.

In our study, although we found that the incidence of sarcopenia increased in early-stage cirrhosis patients like other studies, this sarcopenia was not related to insulin resistance.

Ethics Committee Approval

Approved by the local ethics committee.

Informed Consent

Prospective study.

Peer-review

Internally peer-reviewed.

Authorship Contributions

Concept: E.S.M., B.A., B.S.H., S.M.; Design: E.S.M., B.A., B.S.H., S.M.; Supervision: E.S.M., B.A., B.S.H., S.M.; Fundings: E.S.M.,; Materials: E.S.M.;; Data: E.S.M., B.A.; Analysis: E.S.M., B.S.H.; Literature search: E.S.M., B.A., S.M.;; Writing: E.S.M., S.B.; Critical revision: E.S.M., S.B.

Conflict of Interest

None declared.

\section{REFERENCES}

1. Italian Multicentre Cooperative Project on Nutrition in Liver Cirrhosis. Nutritional status in cirrhosis. J Hepatol 1994;21:317-25. [CrossRef]

2. Müller MJ, Pirlich M, Balks HJ, Selberg O. Glucose intolerance in liver cirrhosis: role of hepatic and non-hepatic influences. Eur J Clin Chem Clin Biochem 1994;32:749-58. [CrossRef]

3. TÜRKDİAB İnsülin Direnci Çalıştayı Sonuç Raporu 2017:23-4.

4. Srikanthan P, Karlamangla AS. Relative muscle mass is inversely associated with insulin resistance and prediabetes. Findings from the third National Health and Nutrition Examination Survey. J Clin Endocrinol Metab 2011;96:2898-903. [CrossRef]

5. Burton LA, Sumukadas D. Optimal management of sarcopenia. Clin Interv Aging 2010;5:217-28. [CrossRef]

6. Janssen I, Baumgartner RN, Ross R, Rosenberg IH, Roubenoff R. Skeletal muscle cutpoints associated with elevated physical disability risk in older men and women. Am J Epidemiol 2004;159:413-21.

7. Guglielmi FW, Panella C, Buda A, Budillon G, Caregaro L, Clerici C, et al. Nutritional state and energy balance in cirrhotic patients with or without hypermetabolism. Multicentre prospective study by the 'Nutritional Problems in Gastroenterology' Section of the Italian Society of Gastroenterology (SIGE). Dig Liver Dis 2005;37:681-8.

8. Lochs H, Allison SP, Meier R, Pirlich M, Kondrup J, Schneider S, et al. Introductory to the ESPEN Guidelines on Enteral Nutrition: Terminology, definitions and general topics. Clin Nutr 2006;25:180-6.

9. Kyle UG, Genton L, Slosman DO, Pichard C. Fat-free and fat mass percentiles in 5225 healthy subjects aged 15 to 98 years. Nutrition 2001;17:534-41. [CrossRef]

10. Roubenoff R, Baumgartner RN, Harris TB, Dallal GE, Hannan $\mathrm{MT}$, Economos CD, et al. Application of bioelectrical impedance 
analysis to elderly populations. J Gerontol A Biol Sci Med Sci 1997;52:M129-36. [CrossRef]

11. Reusch JE. Current concepts in insulin resistance, type 2 diabetes mellitus, and the metabolic syndrome. Am J Cardiol 2002;90:19G26G. [CrossRef]

12. Barzilaym JI, Freedland ES. Inflammation and its relationship to insulin resistance, type 2 diabetes mellitus, and endothelial dysfunction. Metab Syndr Relat Disord 2003;1:55-67. [CrossRef]

13. Mistık R, Balik I. Turkiyéde Viral Hepatitlerin Epidemiolojik Analizi. Tekeli E, Balik I, editors. Viral Hepatit. Viral Hepatitle Savaşim Dernegi. Istanbul; 2003. p. 9-55.

14. Nishida T, Tsuji S, Tsujii M, Arimitsu S, Haruna Y, Imano E, et al. Oral glucose tolerance test predicts prognosis of patients with liver cirrhosis. Am J Gastroenterol 2006;101:70-5. [CrossRef]

15. Buzzelli G, Chiarantini E, Cotrozzi G, Relli P, Matassi L, Romanelli $\mathrm{RG}$, et al. Estimate of prevalence of glucose intolerance in chronic liver disease. Degree of agreementamong some diagnostic criteria. Liver 1988;8:354-9. [CrossRef]

16. Harrison SA. Liver disease in patients with diabetes mellitus. J Clin Gastroenterol 2006;40:68-76. [CrossRef]

17. Han SH, Martin P. Diabetes mellitus: a predictor of cirrhosis in chronic viral hepatitis. J Clin Gastroenterol 2000;30:227-8. [CrossRef]

18. Petrides AS, Vogt C, Schulze-Berge D, Matthews D, Strohmeyer G.
Pathogenesis of glucose intolerance and diabetes mellitus in cirrhosis. Hepatology 1994;19:616-27. [CrossRef]

19. James OF, Day CP. Non-alcoholic steatohepatitis (NASH): a disease of emerging identity and importance. J Hepatol 1998;29:495-501.

20. Lao TT, Tse KY, Chan LY, Tam KF, Ho LF. HBsAg carrier status and the association between gestational diabetes with increased serumferritin concentration in Chinese women. Diabetes Care 2003;26:3011-6.

21. Sangiorgio L, Attardo T, Gangemi R, Rubino C, Barone M, Lunetta $\mathrm{M}$. Increased frequency of HCV and HBV infection in type 2 diabetic patients. Diabetes Res Clin Pract 2000;48:147-51. [CrossRef]

22. Brandt C, Nielsen AR, Fischer CP, Hansen J, Pedersen BK, Plomgaard P. Plasma and muscle myostatin in relation to type 2 diabetes. PLoS One 2012;7:e37236. [CrossRef]

23. Stump CS, Henriksen EJ, Wei Y, Sowers JR. The metabolic syndrome: role of skeletal muscle metabolism. Ann Med 2006;38:389402. [CrossRef]

24. Cesari M, Leeuwenburgh C, Lauretani F, Onder G, Bandinelli S, Maraldi C, et al. Frailty syndrome and skeletal muscle: results from the Invecchiare in Chianti study. Am J Clin Nutr 2006;83:1142-8.

25. Lauretani F, Russo CR, Bandinelli S, Bartali B, Cavazzini C, Di Iorio A, et al. Age-associated changes in skeletal muscles and their effect on mobility: an operational diagnosis of sarcopenia. J Appl Physiol (1985) 2003;95:1851-60. [CrossRef]

\section{Hepatit B’ye Bağlı Sirotik Hastalarda Kas Kitlesi ile İnsülin Direnci Arasındaki İlişki}

Amaç: Hepatit B virüsü, tüm önlemlere rağmen, dünyada 400 milyon üzerinde kişiyi etkilemekte ve büyük tehdit oluşturmaktadır. Karaciğer sirozunun en önemli nedenlerinden birisidir. Karaciğer sirozu ise hastalı̆ın hem kendinden kaynaklanan, hem de çeşitli nedenlerle oral alımda azalma sonucu malnutrisyona neden olmaktadır. Yapılan çalışmalarda kas kitlesi ile insülin direnci arasında ki ters korelasyon belirlenmiştir. Biz hepatit B nedeniyle siroz gelişen hastalarda insülin direnci ile kas kitlesi ve kas gücü arasında ki ilişkiyi değerlendirmeyi amaçladık.

Gereç ve Yöntem: Tek merkezli olarak yönetilen bu çalışmaya 65 hepatit B'ye bağlı Child A ve Child B grubundaki sirotik hastalar ile 65 kontrol hastası dahil edilmiştir. Her iki grupta kas gücünü ve kitlesini belirlemek amacı ile bioempedans analiz ile kas kitle indeksi (kas kitlesi $/ b^{2}{ }^{2}, \mathrm{~kg} / \mathrm{m}^{2}$ ) hesaplandı. El sıkma gücü, kol ve baldır çevresi bakıldı. Her iki grupta insülin direncinin belirlenmesi amacı ile HOMA-IR [(açlık insülin $\mu \mathrm{U} / \mathrm{mL}) \times(A K S ̧ m m o l / L) / 22.5]$ bakıldı. Her iki gruptan açlık insülin, açlık glukoz, HbAlc, LDL, HDL, trigliserit, kolesterol düzeyleri, baldır çevresi ile bel çevresi bakıldı. Kas kitlesi ile insülin direnci, laboratuvar değerleri, bel çevresi ve baldır çevresi arasındaki ilişki değerlendirildi.

Bulgular: Çalışmamızda, hasta grubunun kas kitle indeksi ortalaması 10.98 \pm 11.40 , kontrol grubunun kas kitle ortalaması $9.88 \pm 1.12$ olarak belirlendi. HOMA-IR değeri ise hasta katılımcılarda $3.47 \pm 3.80$, kontrol grubunda ise $1.83 \pm 1.20$ olarak belirlendi. Özellikle hasta grubunda bakılan kas kitlesi ile insülin direnci arasında hesaplanan korelasyon katsayısı istatistiksel olarak anlamlı bulunmamıştır.

Sonuç: Çalışmamızda hepatit B'ye bağlı sirotik hastalarda kas kitlesi ile insülin direnci arasında ilişki bulunmamıştır.

Anahtar Sözcükler: Hepatit B; insülin direnci; kas kitlesi; siroz. 